\title{
Cohnella xylanilytica sp. nov. and Cohnella terrae sp. nov., xylanolytic bacteria from soil
}

\author{
Saowapar Khianngam, ${ }^{1}$ Somboon Tanasupawat, ${ }^{1}$ \\ Ancharida Akaracharanya, ${ }^{2}$ Kwang Kyu Kim, ${ }^{3}$ Keun Chul Lee ${ }^{3}$ \\ and Jung-Sook Lee ${ }^{3}$
}

Correspondence

Somboon Tanasupawat Somboon.T@chula.ac.th Jung-Sook Lee jslee@kribb.re.kr

\author{
${ }^{1}$ Department of Biochemistry and Microbiology, Faculty of Pharmaceutical Sciences, Chulalongkorn \\ University, Bangkok 10330, Thailand \\ ${ }^{2}$ Department of Microbiology, Faculty of Science, Chulalongkorn University, Bangkok 10330, \\ Thailand \\ ${ }^{3}$ Korean Collection for Type Cultures, Biological Resource Center, Korea Research Institute of \\ Bioscience and Biotechnology, Yuseong, Daejeon 305-806, Republic of Korea
}

Two xylan-degrading bacteria, strains $M X 15-2^{\top}$ and $M X 21-2^{\top}$, were isolated from soils collected in Nan province, Thailand. Cells were Gram-reaction-positive, facultatively anaerobic, sporeforming and rod-shaped. They contained meso-diaminopimelic acid in the cell-wall peptidoglycan. The major menaquinone was MK-7. iso- $\mathrm{C}_{16: 0}$ and anteiso- $\mathrm{C}_{15: 0}$ were the predominant cellular fatty acids. Diphosphatidylglycerol, phosphatidylglycerol, phosphatidylethanolamine and lysylphosphatidylglycerol were the major polar lipids. The genomic DNA G+C contents of strains MX15-2 $2^{\top}$ and MX21-2 ${ }^{\top}$ were 63.0 and 65.1 mol\%, respectively. Phylogenetic analysis using $16 \mathrm{~S}$ rRNA gene sequences showed that strains $M X 15-2^{\top}$ and $M X 21-2^{\top}$ were affiliated with the genus Cohnella and were closely related to Cohnella thermotolerans CCUG $47242^{\top}$, with 96.5 and $95.6 \%$ sequence similarity, respectively. The strains could be clearly distinguished from each other and from all known species of the genus Cohnella based on their physiological and biochemical characteristics as well as their phylogenetic positions and levels of DNA-DNA hybridization. Therefore, these two strains represent novel species of the genus Cohnella, for which the names Cohnella xylanilytica sp. nov. (type strain MX15-2 ${ }^{\top}=$ KCTC $22294^{\top}=$ PCU $309^{\top}=$ TISTR $1891^{\top}$ ) and Cohnella terrae sp. nov. (type strain MX21-2 ${ }^{\top}=$ KCTC $22295^{\top}=$ PCU $310^{\top}=$ TISTR $1892^{\top}$ ) are proposed.
The genus Cohnella was proposed by Kämpfer et al. (2006) and the type species is Cohnella thermotolerans. Members of the genus Cohnella are Gram-positive, spore-forming, aerobic, motile or non-motile, thermotolerant, rod-shaped bacteria. At the time of writing, the genus Cohnella contains nine species, C. thermotolerans isolated from a sample of industrial starch production in Sweden, Cohnella hongkongensis from a Chinese patient with neutropenic fever, Cohnella laeviribosi from a volcanic area in Likupang, Indonesia, Cohnella phaseoli from root nodules of

Abbreviations: MR, methyl red; VP, Voges-Proskauer.

The GenBank/EMBL/DDBJ accession numbers for the $16 \mathrm{~S}$ rRNA gene sequences of strains $M \times 15-2^{\top}$ and $M \times 21-2^{\top}$ are FJ001841 and FJ001842, respectively.

An SEM of strains $M \times 15-2^{\top}$ and $M \times 21-2^{\top}$, two phylogenetic trees showing relationships between strains $M \times 15-2^{\top}$ and $M X 21-2^{\top}$, known species of the genus Cohnella, and other related taxa, and polar lipid profiles of the two strains are available as supplementary material with the online version of this paper.
Phaseolus coccineus in Spain, Cohnella fontinalis from fresh water in Japan, Cohnella luojiensis from soil of a Euphrates poplar forest in Xinjiang, China, Cohnella yongneupensis and Cohnella ginsengisoli from wetland and ginseng soils in Korea and Cohnella thailandensis from soil in Thailand (Teng et al., 2003; Kämpfer et al., 2006; Cho et al., 2007; García-Fraile et al., 2008; Shiratori et al., 2010; Cai et al., 2010; Kim et al., 2010; Khianngam et al., 2010). In this paper, we present the characterization of two novel xylanolytic bacteria belonging to the genus Cohnella by means of a polyphasic taxonomic study.

MX15-2 $2^{\mathrm{T}}$ and MX21-2 ${ }^{\mathrm{T}}$ were isolated from soil samples collected in Muang district, Nan province, Thailand, by the spread plate method on XC agar medium containing $\left(1^{-1}\right)$ : $10 \mathrm{~g}$ oat spelt xylan, $5 \mathrm{~g}$ peptone, $1 \mathrm{~g}$ yeast extract, $4 \mathrm{~g}$ $\mathrm{K}_{2} \mathrm{HPO}_{4}, 1 \mathrm{~g} \mathrm{MgSO}_{4} .7 \mathrm{H}_{2} \mathrm{O}, 0.2 \mathrm{~g} \mathrm{KCl}, 0.02 \mathrm{~g} \mathrm{FeSO}_{4} .7 \mathrm{H}_{2} \mathrm{O}$, $15 \mathrm{~g}$ agar $(\mathrm{pH}$ 7.0). In this screening step, agar plates were incubated at $40{ }^{\circ} \mathrm{C}$ for 2 days. Xylanase-producing capacity of the cultures was detected by using a Congo red overlay 
method, as reported previously (Teather \& Wood, 1982; Ruijssenaars \& Hartsmans, 2001). Isolates showing xylanase-producing capacity were transferred to $\mathrm{C}$ agar medium. This medium had the same composition as XC medium without the oat spelt xylan. Colonies grown on $\mathrm{C}$ agar medium were examined for their morphological and cultural characteristics, including cell shape, colony appearance, endospore formation and pigmentation, after incubation at $37^{\circ} \mathrm{C}$ for 2 days. Critical-point-dried cells were observed under a scanning electron microscope. Flagella were stained by the method described by Forbes (1981). Physiological and biochemical characterization was performed using API $20 \mathrm{NE}$ and API $50 \mathrm{CH}$ strips combined with API $50 \mathrm{CHB} / \mathrm{E}$ medium (bioMérieux), in accordance with the manufacturer's directions. Tests for catalase, oxidase and urease activity, hydrolysis of casein, DNA, starch, Tween 80 and L-tyrosine, the methyl red (MR)/Voges-Proskauer (VP) reactions, indole production, citrate utilization and $\mathrm{H}_{2} \mathrm{~S}$ production were performed as described by Barrow \& Feltham (1993). Growth under anaerobic conditions on agar plates was investigated using a Gaspak (BBL) anaerobic jar. Growth at $\mathrm{pH} 5,6,7,8$ and 9 , in 3 and $5 \%(\mathrm{w} / \mathrm{v}) \mathrm{NaCl}$ and at 10, 15, 20, 25, 30, 40, 45, 50,55 and $60{ }^{\circ} \mathrm{C}$ was tested by using $\mathrm{C}$ agar medium. All tests were carried out by incubating the cultures at $37^{\circ} \mathrm{C}$, except for investigations into the effect of temperature on growth.

Detection of menaquinones and cell-wall diaminopimelic acid was performed as described by Komagata \& Suzuki (1987). For total cellular fatty acid analyses, cells were grown on tryptic soy agar (TSA; Difco) for $48 \mathrm{~h}$ at $30{ }^{\circ} \mathrm{C}$, and the standard Microbial Identification System (MIDI) was used for automated GC analyses (Sasser, 1990). Polar lipids were extracted, examined by two-dimensional TLC and identified by using published procedures (Minnikin et al., 1977). Polar lipids were characterized with spray reagents specific for sugars ( $\alpha$-naphthol/ $/ \mathrm{H}_{2} \mathrm{SO}_{4}$ and anisaldehyde $/ \mathrm{H}_{2} \mathrm{SO}_{4}$ ), phosphate (Zindzadze), free amino groups (ninhydrin) and quaternary nitrogen compounds (Dragendorff). The spots were identified by referring to previous descriptions of polar lipid profiles from species of the genus Cohnella (Kämpfer et al., 2006; Cho et al., 2007; Cai et al., 2010).

DNA was prepared by the method of Saito \& Miura (1963). DNA base compositions were determined by reversedphase HPLC (Tamaoka \& Komagata, 1984). Photobiotinlabelled DNA-DNA hybridization was performed in a solution of $2 \times$ SSC and $50 \%$ formamide at $50{ }^{\circ} \mathrm{C}$ for $15 \mathrm{~h}$ (Ezaki et al., 1989). The 16S rRNA genes of the novel strains were amplified, and the PCR products were purified and sequenced as described previously (Tanasupawat et al., 2004). The sequences of strains MX15-2 $2^{\mathrm{T}}$ and MX21-2 (1507 nt and $1553 \mathrm{nt}$, respectively) were aligned with selected sequences obtained from GenBank by using CLUSTAL_X version 1.83 (Thompson et al., 1997). The alignment was edited manually to remove gaps and ambiguous nucleotides prior to the construction of phylogenetic trees. Phylogenetic trees were constructed by using neighbour-joining (Saitou \& Nei, 1987) and maximum-parsimony (Fitch, 1971) algorithms in MEGA4 software (Tamura et al., 2007). Confidence values of branches of the phylogenetic trees were determined using bootstrap analyses (Felsenstein, 1985) based on 1000 resamplings.

Cells of strains MX15-2 $2^{\mathrm{T}}$ and $\mathrm{MX} 21-2^{\mathrm{T}}$ were Gramreaction-positive, facultatively anaerobic, motile and rodshaped. Central ellipsoidal endospores were observed in swollen sporangia (Supplementary Fig. S1, available in IJSEM Online). After incubation on $\mathrm{C}$ medium for 2 days, colonies were circular, flat, $1-3.5 \mathrm{~mm}$ in diameter and white. The phenotypic characteristics are listed in the species descriptions and in Tables 1 and 2. In the 16S rRNA gene-based phylogenetic tree reconstructed according to the neighbour-joining method, MX15-2 ${ }^{\mathrm{T}}$ and MX21-2 were placed in a monophyletic cluster consisting of all known species of the genus Cohnella and some closely related species of other genera (Fig. 1). Trees constructed by the neighbour-joining and maximum-parsimony methods including strains MX15-2 $2^{\mathrm{T}}, \mathrm{MX} 21-2^{\mathrm{T}}$, species of the genus Cohnella and related taxa are available as Supplementary Figs S2 and S3. Strains MX15- ${ }^{\mathrm{T}}$ and MX21-2 ${ }^{\mathrm{T}}$ were closely related to each other $(97.2 \% 16 \mathrm{~S}$ rRNA gene sequence similarity) and to $C$. thermotolerans CCUG $47242^{\mathrm{T}}$ (96.5 and $95.6 \%$, respectively) based on $16 \mathrm{~S}$ rRNA gene sequence similarity. The two strains showed 93.8-95.2\% similarity with $C$. thailandensis $\mathrm{S} 1-3^{\mathrm{T}}$ and $C$. ginsengisoli GR21-5 ${ }^{\mathrm{T}}$. The DNA-DNA relatedness between strains MX15- $2^{\mathrm{T}}$ and $\mathrm{MX} 21-2^{\mathrm{T}}$ was $52.9 \%$ and both strains showed low levels of DNA-DNA relatedness to $C$. thermotolerans CCUG $47242^{\mathrm{T}}(2.1-5.5 \%)$. The genomic DNA G + C contents of strains MX15-2 $2^{\mathrm{T}}$ and MX21-2 were 63.0 and $65.1 \mathrm{~mol} \%$, respectively, which were in the range of values observed for other members of the genus Cohnella (Kämpfer et al., 2006; Khianngam et al., 2010). Strains MX15-2 ${ }^{\mathrm{T}}$ and MX21-2 ${ }^{\mathrm{T}}$ contained iso- $\mathrm{C}_{16: 0}$ (36.1$39.2 \%)$, anteiso- $\mathrm{C}_{15: 0}(31.6 \%)$ and iso- $\mathrm{C}_{15: 0}(7.5-8.3 \%)$ as the predominant cellular fatty acids. These two strains showed similar cellular fatty acid profiles to C. thermotolerans CCUG $47242^{\mathrm{T}}$, but significant quantitative differences were also found (Table 2). Strains $M X 15-2^{T}$ and MX21-2 $2^{\mathrm{T}}$ contained meso-diaminopimelic acid in the cellwall peptidoglycan, as do species of the genera Bacillus, Paenibacillus (Shida et al., 1997) and Cohnella as described in the emended genus description by Khianngam et al. (2010). The major menaquinone was MK-7. The major polar lipids were diphosphatidylglycerol, phosphatidylglycerol, phosphatidylethanolamine and lysyl-phosphatidylglycerol. Unknown phospholipids and aminophospholipids were also detected (Supplementary Fig. S4). Strains MX15$2^{\mathrm{T}}$ and MX21-2 $2^{\mathrm{T}}$ could be differentiated from each other by differences in growth at $50{ }^{\circ} \mathrm{C}$, the hydrolysis of DNA, the assimilation of carbohydrates and acid production from Larabitol, 5 -ketogluconate, $\alpha$-mannopyranoside, D-mannitol, melezitose and D-tagatose. They were distinguished from 
Table 1. Differential characteristics of strains $M X 15-2^{\top}$ and $M X 21-2^{\top}$ and type strains of related species of the genus Cohnella

Strains: 1 , MX15-2 $2^{\mathrm{T}} ; 2$, MX21-2 ${ }^{\mathrm{T}} ; 3$, C. thermotolerans CCUG $47242^{\mathrm{T}}$; 4, C. thailandensis KCTC $22296^{\mathrm{T}} ; 5$, C. ginsengisoli GR21- $5^{\mathrm{T}}$. Data for related type strains were obtained from this study and Khianngam et al. (2010) unless otherwise indicated. All strains are positive for catalase, oxidase, growth at $\mathrm{pH} 6-9$ and $20,25,30$ and $40{ }^{\circ} \mathrm{C}$, hydrolysis of aesculin, PNPG and starch and acid production from aesculin, amygdalin, $\mathrm{D}$-fructose, glycogen, $\mathrm{D}-$ ribose, starch, turanose and $\beta$-xylopyranoside. All strains are negative for growth in $5 \% \mathrm{NaCl}$, growth at $60{ }^{\circ} \mathrm{C}$, fermentation of glucose, indole production, hydrogen sulfide production, MR and VP reactions, hydrolysis of L-arginine, casein and L-tyrosine, assimilation of $N$-acetylglucosamine, adipic acid, capric acid and phenylacetic acid and acid production from $\mathrm{N}$ acetylglucosamine, D-adonitol, dulcitol, erythritol, D-fucose, gluconate, inositol, inulin, 2-ketogluconate and L-sorbose. w, Weakly positive.

\begin{tabular}{|lccccc|}
\hline Characteristic & $\mathbf{1}$ & $\mathbf{2}$ & $\mathbf{3}$ & $\mathbf{4}$ & $\mathbf{5}$ \\
\hline Growth at/in: & & & & & \\
$3 \%$ NaCl & $\mathrm{w}$ & - & $\mathrm{w}$ & + & - \\
$\mathrm{pH} 5$ & - & + & - & - & + \\
10 and $15{ }^{\circ} \mathrm{C}$ & - & - & - & - & + \\
$45{ }^{\circ} \mathrm{C}$ & + & + & + & + & - \\
$50{ }^{\circ} \mathrm{C}$ & $\mathrm{W}$ & - & + & + & - \\
$55{ }^{\circ} \mathrm{C}$ & - & - & + & - & - \\
Citrate utilization & - & - & - & - & $\mathrm{w}$ \\
Nitrate reduction & - & - & - & - & + \\
Urease & - & - & - & - & + \\
Hydrolysis of DNA & + & - & - & - & - \\
Gelatin & $\mathrm{W}$ & + & + & + & - \\
Tween 80 & + & + & + & - & - \\
Assimilation of: & & & & & \\
L-Arabinose & + & - & + & + & - \\
D-Glucose & + & - & + & + & + \\
Malic acid & + & - & - & - & w \\
Maltose & + & - & - & - & - \\
D-Mannitol & + & - & - & + & - \\
D-Mannose & + & - & + & + & - \\
Potassium gluconate & + & + & - & - & - \\
Acid production from: & & & & & \\
D-Arabinose & + & + & + & w & - \\
L-Arabinose & + & + & - & + & - \\
D-Arabitol & + & + & - & - & - \\
L-Arabitol & - & + & - & - & - \\
Arbutin & + & + & - & + & + \\
Cellobiose & + & + & - & + & + \\
L-Fucose & + & + & - & + & - \\
D-Galactose & + & + & + & + & - \\
Gentiobiose & + & + & - & + & + \\
$\alpha$-Glucopyranoside & + & + & - & + & - \\
Glucose & + & + & - & + & + \\
Glycerol & - & - & - & - & + \\
5-Ketogluconate & - & + & - & - & - \\
Lactose & + & + & - & + & + \\
D-Lyxose & + & + & + & - & - \\
$\alpha$-Mannopyranoside & - & + & + & - & - \\
Maltose & + & + & - & + & + \\
\hline & & & & & \\
\hline
\end{tabular}

Table 1. cont.

\begin{tabular}{|lccccc|}
\hline Characteristic & $\mathbf{1}$ & $\mathbf{2}$ & $\mathbf{3}$ & $\mathbf{4}$ & $\mathbf{5}$ \\
\hline D-Mannitol & + & - & - & + & + \\
D-Mannose & + & + & - & + & + \\
Melezitose & - & + & - & + & - \\
Melibiose & + & + & - & + & + \\
Raffinose & + & + & - & + & + \\
L-Rhamnose & + & + & - & + & - \\
Salicin & + & + & - & + & + \\
D-Sorbitol & + & + & - & - & - \\
Sucrose & + & + & - & + & + \\
D-Tagatose & - & + & - & - & - \\
Trehalose & + & + & - & + & + \\
Xylitol & + & + & + & - & - \\
D-Xylose & + & + & - & + & + \\
L-Xylose & - & - & + & - & - \\
DNA G + C content & 63.0 & 65.1 & $59^{a}$ & $53.3^{b}$ & $61.3^{c}$ \\
$\quad$ mol\%) & & & & & \\
\hline
\end{tabular}

Data from: $a$, Kämpfer et al. (2006); b, Khianngam et al. (2010); c, Kim et al. (2010).

Table 2. Cellular fatty acid compositions of strain $M X 15-2^{\top}$, $M X 21-2^{\top}$ and type strains of related species of the genus Cohnella

Strains: 1, MX15-2 $2^{\mathrm{T}} ; 2, \mathrm{MX} 21-2^{\mathrm{T}} ; 3$, C. thermotolerans CCUG $47242^{\mathrm{T}}$; 4, Cohnella thailandensis KCTC $22296^{\mathrm{T}}$; 5 , C. ginsengisoli GR21-5 ${ }^{\mathrm{T}}$. Data in columns 3-5 were obtained from Khianngam et al. (2010). Values are percentages of total fatty acids. - , Not detected; tr, trace $(<1 \%)$.

\begin{tabular}{|lccccc|}
\hline Fatty acids & $\mathbf{1}$ & $\mathbf{2}$ & $\mathbf{3}$ & $\mathbf{4}$ & $\mathbf{5}$ \\
\hline Straight-chain saturated & & & & & \\
$\mathrm{C}_{10: 0}$ & - & - & $\operatorname{tr}$ & - & - \\
$\mathrm{C}_{12: 0}$ & - & - & $\operatorname{tr}$ & - & - \\
$\mathrm{C}_{14: 0}$ & $\operatorname{tr}$ & $\operatorname{tr}$ & 1.5 & 1.8 & 5.5 \\
$\mathrm{C}_{15: 0}$ & 2.0 & 4.5 & 1.1 & 5.2 & 1.5 \\
$\mathrm{C}_{16: 0}$ & 5.4 & 5.4 & 6.8 & 7.7 & 16.2 \\
$\mathrm{C}_{17: 0}$ & $\operatorname{tr}$ & $\operatorname{tr}$ & - & $\operatorname{tr}$ & - \\
Branched saturated & & & & & \\
iso-C $\mathrm{C}_{11: 0}$ & - & - & - & $\operatorname{tr}$ & - \\
iso- $\mathrm{C}_{14: 0}$ & 3.0 & 3.2 & 3.4 & 4.4 & 3.8 \\
iso- $\mathrm{C}_{15: 0}$ & 7.5 & 8.3 & 4.4 & 7.5 & 9.2 \\
iso- $\mathrm{C}_{16: 0}$ & 39.2 & 36.1 & 48.3 & 39.5 & 18.9 \\
iso- $\mathrm{C}_{17: 0}$ & 2.1 & 2.1 & 1.1 & 1.9 & 1.2 \\
anteiso- $\mathrm{C}_{11: 0}$ & - & - & - & $\operatorname{tr}$ & - \\
anteiso- $\mathrm{C}_{15: 0}$ & 31.6 & 31.6 & 26.9 & 26.8 & 40.8 \\
anteiso- $\mathrm{C}_{17: 0}$ & 6.4 & 5.6 & 4.8 & 3.8 & 2.9 \\
Unsaturated & & & & & \\
$\mathrm{C}_{16: 1} \omega 7 c$ alcohol & $\operatorname{tr}$ & $\operatorname{tr}$ & $\operatorname{tr}$ & - & - \\
$\mathrm{C}_{16: 1} \omega 11 c$ & - & - & $\operatorname{tr}$ & - & - \\
$\mathrm{C}_{17: 1} \omega 6 c$ & $\operatorname{tr}$ & $\operatorname{tr}$ & $\operatorname{tr}$ & - & - \\
& & & & & \\
\hline
\end{tabular}




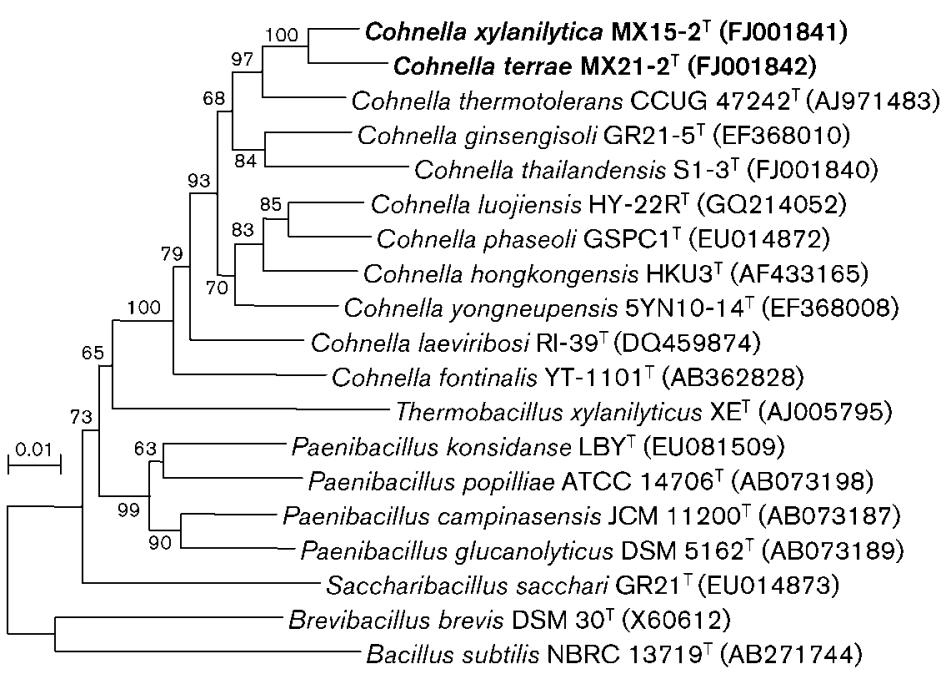

Fig. 1. Neighbour-joining tree based on $16 \mathrm{~S}$ rRNA gene sequences, showing the phylogenetic relationships between strains MX15$2^{\top}$ and MX21-2 ${ }^{\top}$, known species of the genus Cohnella, and other related taxa. Based on 1000 resamplings, bootstrap percentages above $50 \%$ are shown. Bar, 0.01 substitutions per nucleotide position. other species of the genus Cohnella by differences in growth in $3 \% \mathrm{NaCl}$, at $\mathrm{pH} 5$ and at 10,15 and $55{ }^{\circ} \mathrm{C}$, citrate utilization, nitrate reduction, the hydrolysis of DNA, gelatin and Tween 80, assimilation and acid production from carbon sources and the DNA G $+\mathrm{C}$ contents, as listed in Table 1 (Kämpfer et al., 2006; Khianngam et al., 2010; Kim et al., 2010). Based on their phenotypic characteristics and phylogenetic positions, strains MX15-2 ${ }^{\mathrm{T}}$ and MX21-2 represent novel species of the genus Cohnella, for which the names Cohnella xylanilytica sp. nov. and Cohnella terrae sp. nov., respectively, are proposed.

\section{Description of Cohnella xylanilytica sp. nov.}

Cohnella xylanilytica (xy.la.ni.ly'ti.ca. N.L. neut. n. xylanum xylan; N.L. fem. adj. lytica from Gr. masc. adj. lytikos able to loose, dissolving; N.L. fem. adj. xylanilytica xylandissolving).

Cells are Gram-reaction-positive, rod-shaped (0.3-0.5 × 1.4$3.5 \mu \mathrm{m}$ ), facultatively anaerobic and motile by means of peritrichous flagella. Central ellipsoidal endospores are observed in swollen sporangia. After 2 days of incubation on $\mathrm{C}$ agar medium, colonies are $1-3 \mathrm{~mm}$ in diameter, circular, flat and white. Grows in $3 \%(\mathrm{w} / \mathrm{v}) \mathrm{NaCl}$ (weakly), at $\mathrm{pH} 6-9$, at $20-45{ }^{\circ} \mathrm{C}$ and at $50{ }^{\circ} \mathrm{C}$ (weakly) and under anaerobic conditions. Does not grow in $5 \%(\mathrm{w} / \mathrm{v}) \mathrm{NaCl}$, at $\mathrm{pH} 5$ or at $10,15,55$ or $60^{\circ} \mathrm{C}$. Positive for catalase and oxidase activity, hydrolysis of aesculin, DNA, starch, Tween 80 and gelatin (weak), assimilation of L-arabinose, D-glucose, malic acid, maltose, D-mannitol, D-mannose and potassium gluconate. Negative for citrate utilization, indole production, $\mathrm{H}_{2} \mathrm{~S}$ production, $\mathrm{MR}$ and $\mathrm{VP}$ reactions, nitrate reduction and urease activity, hydrolysis of L-arginine, casein and L-tyrosine and assimilation of $\mathrm{N}$-acetylglucosamine, adipic acid, capric acid and phenylacetic acid. Acid is produced from aesculin, amygdalin, D- and L-arabinose, D-arabitol, arbutin, cellobiose, D-fructose, L-fucose, D-galactose, gentiobiose, $\alpha$-glucopyranoside, glucose, glycogen, lactose, D-lyxose, maltose, D-mannitol, D-mannose, melibiose, raffinose, L-rhamnose,
D-ribose, salicin, D-sorbitol, starch, sucrose, trehalose, turanose, $\beta$-xylopyranoside, xylitol and D-xylose. No acid production from $\mathrm{N}$-acetylglucosamine, D-adonitol, L-arabitol, dulcitol, erythritol, D-fucose, gluconate, glycerol, myoinositol, inulin, 2-ketogluconate, 5-ketogluconate, $\alpha$-mannopyranoside, melezitose, L-sorbose, D-tagatose and L-xylose. MK-7 is the predominant menaquinone. The predominant fatty acids are iso- $\mathrm{C}_{16: 0}$ and anteiso- $\mathrm{C}_{15: 0}$. The cell-wall diamino acid is meso-diaminopimelic acid. Major polar lipids are diphosphatidylglycerol, phosphatidylglycerol, phosphatidylethanolamine and lysyl-phosphatidylglycerol. Unknown phospholipids and aminophospholipids are present. The genomic DNA G $+\mathrm{C}$ content of the type strain is $63.0 \mathrm{~mol} \%$.

The type strain is MX15-2 $2^{\mathrm{T}}\left(=\mathrm{KCTC} 22294^{\mathrm{T}}=\mathrm{PCU} 309^{\mathrm{T}}\right.$ $=$ TISTR $1891^{\mathrm{T}}$ ).

\section{Description of Cohnella terrae sp. nov.}

Cohnella terrae (ter'rae. L. gen. n. terrae of the earth).

Cells are Gram-reaction-positive, rod-shaped (0.3$0.5 \times 1.5-4.0 \mu \mathrm{m}$ ), facultatively anaerobic and motile by means of peritrichous flagella. Central ellipsoidal endospores are observed in swollen sporangia. After 2 days of incubation on $C$ agar medium colonies are $1-3.5 \mathrm{~mm}$ in diameter, circular, flat and white. Grows at pH 5-9, 20$45{ }^{\circ} \mathrm{C}$ and under anaerobic conditions. No growth in 3$5 \%(\mathrm{w} / \mathrm{v}) \mathrm{NaCl}$ or at $10,15,50,55$ or $60{ }^{\circ} \mathrm{C}$. Positive for catalase and oxidase activity, hydrolysis of aesculin, gelatin, starch and Tween 80 and assimilation of potassium gluconate. Negative for citrate utilization, indole production, $\mathrm{H}_{2} \mathrm{~S}$ production, $\mathrm{MR}$ and $\mathrm{VP}$ reactions, nitrate reduction, urease activity, hydrolysis of L-arginine, casein, DNA and L-tyrosine and assimilation of $\mathrm{N}$-acetylglucosamine, adipic acid, L-arabinose, capric acid, D-glucose, malic acid, maltose, D-mannitol, D-mannose and phenylacetic acid. Acid is produced from aesculin, amygdalin, D- and L-arabinose, D-arabitol, L-arabitol, arbutin, cellobiose, 
D-fructose, L-fucose, D-galactose, gentiobiose, $\alpha$-glucopyranoside, glucose, glycogen, 5-ketogluconate, lactose, Dlyxose, $\alpha$-mannopyranoside, maltose, D-mannose, melezitose, melibiose, raffinose, L-rhamnose, D-ribose, salicin, Dsorbitol, starch, sucrose, D-tagatose, trehalose, turanose, $\beta$ xylopyranoside, xylitol and D-xylose. No acid production from $\mathrm{N}$-acetylglucosamine, D-adonitol, dulcitol, erythritol, D-fucose, gluconate, glycerol, myo-inositol, inulin, 2ketogluconate, D-mannitol, L-sorbose and L-xylose. MK-7 is the predominant menaquinone. The predominant fatty acids are iso- $\mathrm{C}_{16: 0}$ and anteiso- $\mathrm{C}_{15: 0}$. The cell-wall diamino acid is meso-diaminopimelic acid. Major polar lipids are diphosphatidylglycerol, phosphatidylglycerol, phosphatidylethanolamine and lysyl-phosphatidylglycerol. Unknown phospholipids and aminophospholipids are present. The genomic DNA $\mathrm{G}+\mathrm{C}$ content of the type strain is $65.1 \mathrm{~mol} \%$.

The type strain is MX21-2 $2^{\mathrm{T}}\left(=\mathrm{KCTC} 22295^{\mathrm{T}}=\mathrm{PCU} 310^{\mathrm{T}}\right.$ $=$ TISTR $1892^{\mathrm{T}}$ ).

\section{Acknowledgements}

This work was supported by a Thai Government Research Grant, Chulalongkorn University (2005), a scholarship from the Royal Golden Jubilee PhD Program (2007) awarded to S. K. and a grant from the KRIBB Research Initiative Program, all of which are gratefully acknowledged.

\section{References}

Barrow, G. I. \& Feltham, R. K. A. (1993). Cowan and Steel's Manual for the Identification of Medical Bacteria, 3rd edn. Cambridge: Cambridge University Press.

Cai, F., Wang, Y., Qi, H., Dai, J., Yu, B., An, H., Rahman, E. \& Fang, C. (2010). Cohnella luojiensis sp. nov., isolated from soil of a Euphrates poplar forest. Int J Syst Evol Microbiol 60, 1605-1608.

Cho, E. A., Lee, J.-S., Lee, K. C., Jung, H. C., Pan, J. G. \& Pyun, Y. R. (2007). Cohnella laeviribosi sp. nov., isolated from a volcanic pond. Int J Syst Evol Microbiol 57, 2902-2907.

Ezaki, T., Hashimoto, Y. \& Yabuuchi, E. (1989). Fluorometric deoxyribonucleic acid-deoxyribonucleic acid hybridization in microdilution wells as an alternative to membrane filter hybridization in which radioisotopes are used to determine genetic relatedness among bacterial strains. Int J Syst Bacteriol 39, 224-229.

Felsenstein, J. (1985). Confidence limits on phylogenies: an approach using the bootstrap. Evolution 39, 783-791.

Fitch, W. M. (1971). Toward defining the course of evolution: minimum change for a specific tree topology. Syst Zool 20, 406-416. Forbes, L. (1981). Rapid flagella stain. J Clin Microbiol 13, 807-809. García-Fraile, P., Velázquez, E., Mateos, P. F., Martínez-Molina, E. \& Rivas, R. (2008). Cohnella phaseoli sp. nov., isolated from root nodules of Phaseolus coccineus in Spain, and emended description of the genus Cohnella. Int J Syst Evol Microbiol 58, 1855-1859.
Kämpfer, P., Rosselló-Mora, R., Falsen, E., Busse, H.-J. \& Tindall, B. J. (2006). Cohnella thermotolerans gen. nov., sp. nov., and classification of 'Paenibacillus hongkongensis' as Cohnella hongkongensis sp. nov. Int J Syst Evol Microbiol 56, 781-786.

Khianngam, S., Tanasupawat, S., Akaracharanya, A., Kim, K. K., Lee, K. C. \& Lee, J.-S. (2010). Cohnella thailandensis sp. nov., a xylanolytic bacterium from Thai soil. Int J Syst Evol Microbiol 60, 2284-2287.

Kim, S.-J., Weon, H.-Y., Kim, Y.-S., Anandham, R., Jeon, Y.-A., Hong, S.-B. \& Kwon, S.-W. (2010). Cohnella yongneupensis sp. nov. and Cohnella ginsengisoli sp. nov., isolated from two different soils. Int $J$ Syst Evol Microbiol 60, 526-530.

Komagata, K. \& Suzuki, K. (1987). Lipid and cell-wall analysis in bacterial systematics. Methods Microbiol 19, 161-207.

Minnikin, D. E., Patel, P. V., Alshamaony, L. \& Goodfellow, M. (1977). Polar lipid composition in the classification of Nocardia and related bacteria. Int J Syst Bacteriol 27, 104-117.

Ruijssenaars, H. J. \& Hartsmans, S. (2001). Plate screening methods for the detection of polysaccharase-producing microorganisms. Appl Microbiol Biotechnol 55, 143-149.

Saito, H. \& Miura, K. (1963). Preparation of transforming deoxyribonucleic acid by phenol treatment. Biochim Biophys Acta 72, 619-629.

Saitou, N. \& Nei, M. (1987). The neighbor-joining method: a new method for reconstructing phylogenetic trees. Mol Biol Evol 4, 406425.

Sasser, M. (1990). Identification of bacteria by gas chromatography of cellular fatty acids, MIDI Technical Note 101. Newark, DE: MIDI Inc.

Shida, O., Takagi, H., Kadowaki, K., Nakamura, L. K. \& Komagata, K. (1997). Transfer of Bacillus alginolyticus, Bacillus chondroitinus, Bacillus curdlanolyticus, Bacillus glucanolyticus, Bacillus kobensis, and Bacillus thiaminolyticus to the genus Paenibacillus and emended description of the genus Paenibacillus. Int J Syst Bacteriol 47, 289-298.

Shiratori, H., Tagami, Y., Beppu, T. \& Ueda, K. (2010). Cohnella fontinalis sp. nov., a xylanolytic bacterium isolated from fresh water. Int J Syst Evol Microbiol 60, 1344-1348.

Tamaoka, J. \& Komagata, K. (1984). Determination of DNA base composition by reversed-phase high-performance liquid chromatography. FEMS Microbiol Lett 25, 125-128.

Tamura, K., Dudley, J., Nei, M. \& Kumar, S. (2007). MEGA 4: molecular evolutionary genetics analysis (MEGA) software version 4.0. Mol Biol Evol 24, 1596-1599.

Tanasupawat, S., Thawai, C., Yukphan, P., Moonmangmee, D., Itoh, T., Adachi, O. \& Yamada, Y. (2004). Gluconobacter thailandicus sp. nov., an acetic acid bacterium in the $\alpha$-proteobacteria. J Gen Appl Microbiol 50, 159-167.

Teather, R. M. \& Wood, P. J. (1982). Use of Congo red-polysaccharide interactions in enumeration and characterization of cellulolytic bacteria from the bovine rumen. Appl Environ Microbiol 43, 777-780.

Teng, J. L. L., Woo, P. C. Y., Leung, K. W., Lau, S. K. P., Wong, M. K. M. \& Yuen, K. Y. (2003). Pseudobacteraemia in a patient with neutropenic fever caused by a novel paenibacillus species: Paenibacillus hongkongensis sp. nov. Mol Pathol 56, 29-35.

Thompson, J. D., Gibson, T. J., Plewniak, F., Jeanmougin, F. \& Higgins, D. G. (1997). The CLUSTAL_X windows interface: flexible strategies for multiple sequence alignment aided by quality analysis tools. Nucleic Acids Res 25, 4876-4882. 